\title{
A degree of success for MRes courses
}

[LONDON] A controversial one-year postgraduate degree designed to train students in research skills has been been praised by students, universities and research councils in the United Kingdom, defying widespread scepticism that the course would fail to take off.

The idea of a 'research master's' degree (MRes) received a lukewarm response when suggested by the former Conservative government in its white paper on science and technology policy in 1993. But with the pilot phase now into its third year, several universities have acknowledged that the courses provide a good preparation for a $\mathrm{PhD}$ programme, and last week the government said it will allow sponsoring research councils to continue to fund the course when the pilot phase ends this summer.

Several universities say they have been surprised by the large number of highcalibre students that many MRes courses tend to attract. This trend was confirmed in a report from the four research councils that have been supporting the degree. "We were all a bit sceptical at the start," says Bob Price, director of human and corporate resources at the Biotechnology and Biological Sciences Research Council, one of the sponsoring councils. "No one was totally enthusiastic."

Not everyone has been convinced. The Particle Physics and Astronomy Research Council and the Institute of Physics, for example, remain sceptical about the appropriateness of the MRes approach. They argue that the degree's structure - short project work in one or two subject areas combined with taught courses in research skills - will not be directly relevant to the longer-term research of a $\mathrm{PhD}$.

Philip Diamond, manager of higher education and research at the Institute of Physics, says that the four-year MPhys degree courses supported by the institute are a better preparation for research in physics. About one-third of UK undergraduate physics students are studying for an MPhys degree.

But Price says that most of the universities taking part in the project have been convinced of the degree's uses as an introduction to research skills. Some are even offering MRes programmes funded through nongovernment sources, and many receive students from overseas.

The MRes course can be likened to a 'PhD primer'. Students spend two-thirds of their time undertaking several short, or one longer, research project. The remainder is spent studying taught courses on research skills. The short projects are in a different subject from the student's first degree. The idea is to show that research skills need to be transferable, as full-time researchers often

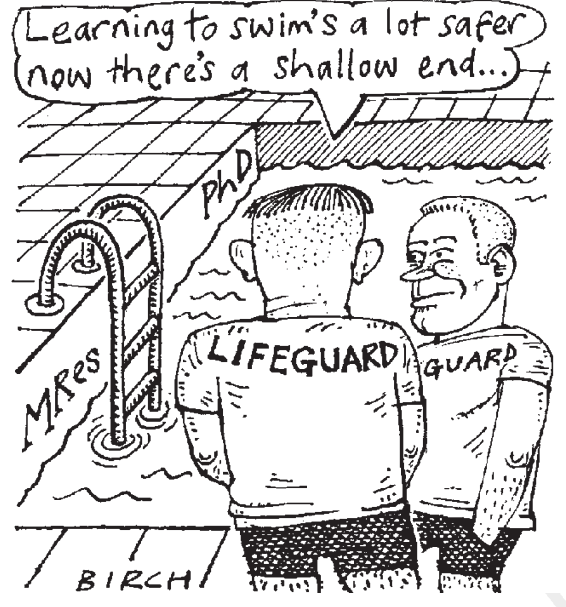

have to change fields or work in multidisciplinary teams.

The origins of the course stemmed from concern that some students embarking on three-year $\mathrm{PhD}$ programmes lacked the confidence or ability to study independently, leading them to drop out. An MRes course would allow them to assess whether or not they were suited to research.

If at the end of the course they choose not to continue with a $\mathrm{PhD}$, they would have a qualification that would also be relevant to industry. Chris Wharton, co-director of the MRes programme at the University of Birmingham, says if he had his way he "would get all $\mathrm{PhD}$ students to do this course".

Wharton says that one of his main worries when the course began was whether it would attract enough high-calibre applicants. This fear appears to have been unfounded. The research council report shows that last year 32 per cent of MRes applicants in the biological sciences came with first-class degrees, compared with just 11 per cent of applicants for conventional master's degrees.

The research councils have supported more than 200 students per year on 30 courses at various UK universities. Courses offered by the medical, natural environment, and biological sciences councils are oversubscribed. In contrast, the Engineering and Physical Sciences Research Council - ironically one of the most enthusiastic supporters of the MRes - is having difficulty attracting suitable students, as a relatively high proportion of those ending their course have been undecided about their future career.

EhsanMasood

\section{Spain lifts block on Framework funds}

[MUNICH] The European Union's next fiveyear Framework programme of research (FP5) has cleared another hurdle in its problem-strewn path towards approval. Contrary to widespread fears, the council of research ministers reached a 'common position' on the European Commission's proposal last week, as Spain was persuaded at the last moment to lift its threatened veto.

This was an important step because of the tight timetable. Second readings in parliament and council are still required, but the programme must be adopted well before the end of the year to ensure that there is no gap in funding for researchers (see Nature 391, 519; 1998).

In its bid to avoid such a gap, the council has had to make a compromise that may cause problems later. Spain is refusing to approve any programme to be financed under the European Union's financial arrangements for the period beyond 2000, whose terms are being negotiated. It is using this weapon to try to force ministers to agree to maintain the union's generous subsidies to Spain after 2000. To sidestep the problem, the council's proposal approves Framework funding only for 1999; continuing funding will depend on the negotiations.

Assuming that funding is continued as planned, the budget of the council's common position is only ECU14 billion (US\$15.2 billion). This figure drew immediate angry responses from both commission and parliament which had put forward ECU16.3 billion and ECU16.7 billion respectively.

Research commissioner Edith Cresson referred to the council's meeting as "black Thursday". She said the funding proposed, which would be less in real terms than the funding for the current five-year programme, was a "negative signal" to industry. She contrasted the council's common position with recent promises of generous increases in US funding for research.

Parliament, which has co-decision rights with the council, will almost certainly reject such a low level of funding, and a conciliation procedure will be required after the second reading. Indeed, it is not yet clear whether parliament will be willing to vote on the council's common position, as it does not provide a definitive budget.

Under pressure from the French research minister, Claude Allègre, the council agreed to set up a ministerial meeting on the management and administration of FP5 at the end of April. Allègre's most radical suggestion - which has attracted little support - is that responsibility for management of the programme should be devolved from Brussels to national research organizations.

Alison Abbott 